\title{
Human Development and Sustainability Nexus: A Third World Perspective
}

\author{
Prince Igwe $^{1}$, Luke Amadi ${ }^{1}$, George Anokwuru ${ }^{1}$ \\ ${ }^{1}$ Department of Political \& Administrative Studies, university of Port Harcourt, Nigeria
}

\begin{abstract}
We explored the human development index (HDI) and point to new sets of research inquiry that suggest bleak nexus between human development and sustainability in the Third World. A critical reengagement with the world systems theory was apt to re-examine possible transformation of the Third World societies as inequality, poverty and improved wellbeing remain global challenges. The paper suggests that such linkages have been dreary as global asymmetry pervades. This divides the world along the affluent North and poor South and partly accounts for systemic distortions at attaining equitable and sustainable human development. It recommends a redefined human development paradigm one which is pro human, pro nature and pro poor premised on equality.
\end{abstract}

Keywords: Human Development, Inequality, Sustainability, Poverty, Underdevelopment, Third World

\section{INTRODUCTION}

The Human development paradigm reinforces the notion of enlarging people's freedoms in what they want to do or be. In practical terms it entails the empowerment of people through their active engagement with development. It is pro-people (UNDP, 1990). There are four groups of the human development namely the very high human development, high human development, medium human development and low human development (UNDP, 2016).

Human Development Index (HDI) is a composite index that measures average achievement. It has three measurement indexes: 1. Life Expectancy Index (LEI): Life expectancy at birth (in years); 2. Education Index (EI) Mean years of schooling (in years), and Expected years of schooling (in years), and 3. Income Index (II): Per capita income (PPP \$). The HDI score that is below 0.5 represents low development.

The 2008 UNDP report indicates that 29 of the 31 countries below the 0.5 level are located in Africa, the others being Haiti and Yeman. The lowest-ranked HDI countries are Sierra Leone, Burkina Faso, Guinea-Bissau, and Niger (UNDP, 2008).

The nexus between human development and sustainability in the Third World jostle for research attention. This is particularly important as the persistent low human development index (HDI) since the 1990s as shown above and increasing poverty, point to new sets of research inquiry and urgent policy response.

Over the years, the focus has been on economic development as economic progress among nations was determined by the attainment of a certain level of GDP by nations.

The ILO's World Employment Programme (WEP) was initiated in 1969 as ILO's response to the forthcoming United Nations Development Decade. What sets the WEP framework apart was not its novel response to unit level analysis of development with emphasis on the Human Basic Needs (HBNs) but how this could be inclusive and equitable.

In particular, how it could become a move away from the largely economic development based models of the past. The Third World was seen as a centre of a new development thinking where people could be employed to meet their basic needs and subsistence. And resist a deferential external influence .The document; Employment, Growth and Basic Needs: A One World Problem was produced by the ILO and handed in at the 1976 ILO World Conference. 


\section{Prince Igwe et al.}

The conventional wisdom about basic needs was to reduce poverty and unemployment and to achieve dramatic human wellbeing. This had international recognition suggesting the saliency of the basic needs approach. In this view, human needs, livelihoods and subsistence were critical drivers of basic needs.

In the 1980s, it was evident that the Western institutional frameworks propagated by the UN failed to evolve an integrated global framework for a "sustainable" basic needs paradigm. Rather there was a re-emergence of economic model by Thatcher and Reagan and, in particular, the Western economic recession and revoking of debt repayment models negatively impacted the economies of the developing societies. This was propagated through the structural adjustment policies (SAPs) of the 1980s.These development impasse and the palpable backlash resulted in gradual demise of the basic needs model. Alternative thinking beyond the neoliberal development trajectories became a global development concern at the end of the Cold War.

In 1990 Pakistani economist Mabub Ul Hag initiated the human development model which was launched in the first annual UNDP human Development report (HDR).It defined human development as "a process of enlarging peoples choices". These choices include a long and healthy life, education, access to resources needed for a decent standard of living. It also include political freedom, guaranteed human rights and personal self-respect (UNDP, 1990). Thereafter, Human Development Reports (HDRs) became an annual UNDP report.

The reports diversified the application of the concept of human development to include a wide range of themes such as the environment, poverty, inequality, gender, globalization etc. Equally, the HDRs uses similar statistical index with the HDI across countries (Alkire,2010:1) .This created new awareness and international attention on human development. Across countries there emerged human development reports. This was bolstered with the setting up of the International Association of Human Development and Capabilities (IAHDC).

Between1990 to 2016 scant studies have attempted an appraisal of the human development paradigm within sustainability contexts particularly among the developing societies of the Third World. The Third World's mixed record of human development index, including the resurgence of chronic diseases, low life expectancy, high incidence of poverty in places like Africa, Latin America and parts of Asia ,the rise in terrorism in the Middle East and growing ecological breakdown in parts of Asia in spite of a fairly good economic performance of China, has led development experts and foreign policy makers to question the verity of human development among poor societies of the South.

Again, in spite of the indexes, on closer inspection, one finds considerable variations between the developing and developed societies and within the developing societies themselves. The so-called "new" indexes of human development were not so coherent nor new in charting a novel development course.

Regarding equality and economic reform of the Third World societies, there seems not to have been any substantial positive result .Several development experts have made useful observation in this regard (Bello, 2003,Stiglitz,2016; Bourguignon, 2016).Thus, the establishment of a strong free-market economy, remains emblematic but less revolutionary .Poverty index between 1990 to 2016 rose persistently(World Bank,2016). Several former World Bank experts distrust capitalism and its linkages with globalization. For instance, Joseph Stiglitz (2016) had linked much of the failures of the market fundamentalism to globalization. At Washington Consensus one central theme that appears to be a missing research agenda is the possible linkages between human development and sustainability.

Our understanding of sustainable human development combines the preservation of both human and environmental species where life exists. This paper contends that human development is sustainable only to the extent that existential needs of humanity are equitably met and the ecosystem protected.It provides the broaderst environment where life could sustainably exist in equal terms.

Thus, the way to bring human concerns back on track is through possible linkages with sustainable development - prioritizing the protection and preservation of human species and the ecosystem. This has reinforced the growing concern with sustainable human development. Anand and Sen (1994:2) 
argue that such concern shows the need to belief that the future generation will receive similar attention like the present. They called for the recognition of human integration as the basis of human development pointing out that this integration underscores a unified life for all irrespective of "nationality, class, gender or community" (Anand \& Sen, 1994:3).

The gradual spread of human development debates in development studies has made it an increasingly relevant tool to measure country specific development index rather than conventional GDP (Mahbub Hag, 1995). Beyond this useful offshoot, a number of critical literature argue on the contrary, that Western development paradigm has been a failure (Sachs, 1992; Escober, 1995; Ferguson, 2006; Weinstein, 2008). For instance, post development debates which emerged since the 1990s provide novel theoretical insights on the failures of the Western development enterprise in the Third World suggesting the persistence of inequality, ecological breakdown, resurgence of new wars and local conflicts, terrorism etc(Escober, 1995; Mazrui, 1995; Klare,1995; Pieterse,2010). This makes the rethinking of Human Development (HD) within the sustainability paradigm inevitable.

This paper argues that novel theoretical perspective to re-examine human development is necessary. It contends that sustainable human development is critical as human development achieved does not mean human development sustained. It assesses the linkages between human development and sustainability and demonstrates how alternative thinking on sustainable human development could help check disparity in human development indices among countries. It builds on the world systems theory to examine the Third World notion of underdevelopment. In particular, to explore the rationalities and assumptions that are embedded in the representational practices surrounding sustainable human development.

The paper is organized as follows; theoretical framework, human development and sustainability: the missing gaps, linking human development to sustainability, discussion and conclusion.

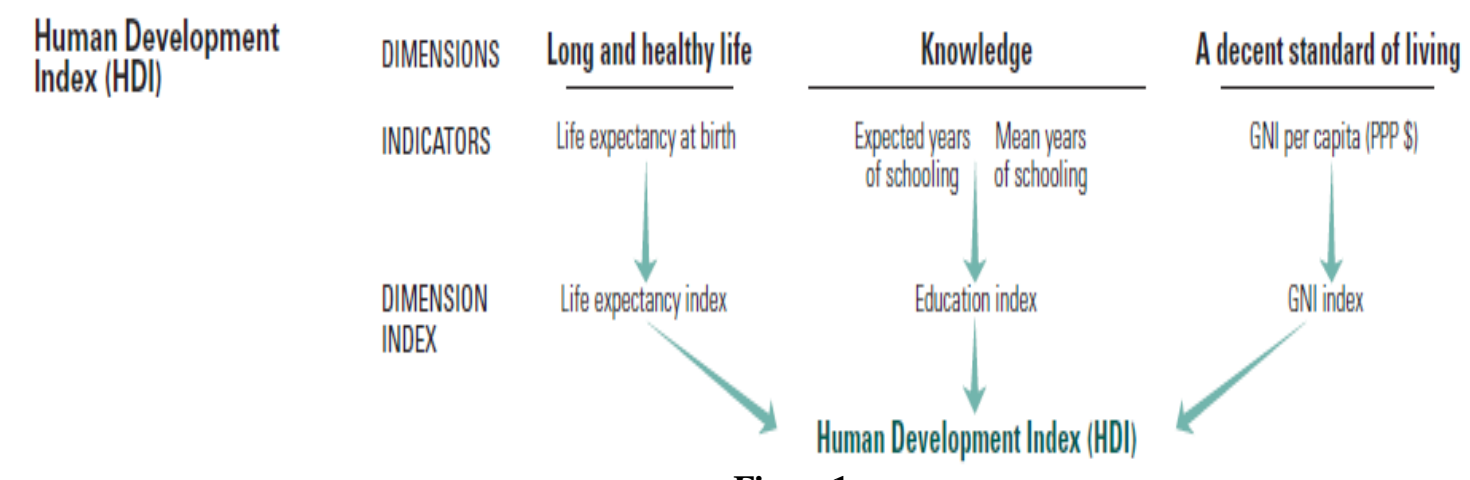

Figure1

Source: UNDP, 2016

\section{THEORETICAL FRAMEWORK}

Several theoretical considerations have been put forward in analyzing human development both from the Marxist and Liberal perspectives. Schultz (1964)provides one of the foremost conceptual debates on improving the qualitative aspect of human resources when he argued that "investment in human capital" is as much an essential part of the processes of economic development as are the more obvious or visible dimensions of industrial progress.

Although there are competing theoretical frameworks on human development and global inequality, neo Marxist debates have been plausible in exploring the inevitable contradictions of inequality. This is informed by the inferred logic of perverse poverty in the societies of the Third World. The present research seeks to enrich that frame of debate within the post development thinking.

Moreover, the contention on 'alternative' sustainable human development model is crucial in elaborating the neglected connections between inequality and human development both at the individual and country levels in an asymmetrical capitalist system. Indeed, the rise of some countries of the South notably China furthers a resurgent rethinking on alternative development model other than the dominant Western model in a process that seemingly paints the Chinese model in a good light against Western imperialism and aid based models. Whereas this is a subject of further research 
in development studies which suggests a critical work, the paper is distinctively concerned with issues related to sustainable human development.

Industrial capitalism and exploitation have given rise to economic dependency (Dos Santos, 1970; Amin, 1972). While the paper deploys a generalized notion of global asymmetry in the context of North/ South divide to describe persistent patterns of "development of underdevelopment" , in line with capitalist imperialism and its divergent forms, it does not lose sight of the internal failures on the part of Third World leadership and poor institutional capacity for radical and strategic development pursuits particularly in Africa.

Beyond this, the paper is largely conceived as a re-engagement with the dependency and world systems debate to describe more explicitly the contextual patterns of inequality constricting sustainable human development. It builds on the Neo-Marxist explanations of development processes, linked to structural inequality.

The world-system which Immanuel Wallerstein (1976) described to be more of an economic rather than a political center creates plausible insight in understanding the international system and inequality. The world systems theory emerged when the major approach to explore Third World development, namely modernization theory, was under serious criticism from various perspectives. Thus, the theory gave novel impetus to this critique as Wallerstein(2000) argued that his aim was to create an alternative explanation. This theory which has been popular in understanding the Third World development crisis reinforced the dependency theory which focuses on understanding the "core" and "periphery" relationship. World-systems theory seeks to explain the dynamics of the "capitalist world economy" as a "total social system". It points out the uneven position and distribution of economic tasks in the world-system. One which legitimizes the exploitation of a group by another within the system. This has flourished in peripheral regions like Latin America, parts of Asia and Africa.

According to Theda Skocpol (1977, p.105), this was a conceptual break with theories of 'modernization' to investigate and understand the development of "capitalism, industrialism, and national states". This suggests the failure of the system to provide socio-economic equality. Anand and Sen (1994:4) argue that the persistence of high premature mortality, illiteracy, ill health, poverty, undernourishment ,insecurity and deprivation indicate the failure of the modern world to provide basic capabilities for all. Thus, there has been growing analytical tension on inequality and sustainable human development nexus which snuggly justifies the theoretical basis of the world systems debate.

Essentially, because of the primacy of inequality in development contexts and unequal opportunities across nations, the world systems theory has been embraced in development studies and in particular makes the global inequality debate a political and scholarly endeavor. This framework will guide the arguments advanced in this study in understanding human development and sustainability disparity among the high, middle and low income countries.

\section{HUMAN DEVELOPMENT AND SUSTAINABILITY: THE MISSING GAPS}

In the last 25 years or so, the evolution of the human development debate has witnessed a rise in research and policy discourse. The linkages between human development and sustainability appear unrealistic and less clear despite a volume of studies and writings on human development. This is partly attributable to scant literature specifically attempting such linkages and interrogating the increasing low human development index in the poor societies despite a fair record of research and scholarship on human development.

Sustainable development emerged in the development discourse in 1987 following the Brundtland commission report which defined it as a development that meets the needs of the present generation without compromising the ability of the future from meeting theirs ( WCED,1987). Sustainable human development (SHD) concept on its part, focuses on preserving present human wellbeing without jeopardizing future human wellbeing (Anand \& Sen, 1994). SHD underscores meeting the development needs of "successor generations as our predecessor did for us" (UNDP, 1994:18). The 1996 HDR (p.56) argued, "Sustainable human development meets the needs of the present generation without compromising the ability of future generations to meet their needs". 
Human development aims to sustain positive outcomes steadily over time. It is prioritized in relation to issues of equality, human rights etc. The 1990 HDR suggests that "growth accompanied by an equitable distribution of income appears to be the most effective means of sustainable human development" (UNDP, 1990). Thus ,intergenerational equity is also linked to sustainable human development(Goodland,1995;UNDP,1996).However a number of studies suggest that growth is strictly not sufficient or necessary for sustained human development (Bourguignon, et al., 2008).

Indicators such as growth have not been attained or adhered to in strict development contexts. Human development and sustainability nexus as explored in development studies is premised on meeting the present development needs of humanity without compromising the ability of the future generations from meeting theirs. It is pro poor, human-centric and pro -environment. It is linked to creating and sustaining an equitable and inclusive environment for humanity and the ecosystem. These include poverty reduction, equality, reduction in unsustainable production and consumption, economic freedom, human security, ecological justice etc.

Human development appears not to have matched the values of the poor who are the majority in the society. There is inequality within and between countries as a number of studies and reports point out since the 1990s including gender, trade, globalization (Stiglitz, 2003; Piketty \& Saez, .2003; Birdsal,2005).Inequality has been examined within various contexts using various indicators such as income index (World Bank,2016),Standard of living (Birdsal,2005),poverty and life expectancy (Narayan, et al;2000). These indicators suggest increasing inequality. Narayan, et a;1(2000)re-echoed hearing the "voice of the poor".

The rise in ecological breakdown remains at issue and a palpable threat to sustainable human development. Humanity cannot develop amidst ecological crisis. Although since the 1990s, the environment and ecosystem have been given priority attention in most of the global human development reports, the challenges of global warming and climate change persist and formed part of the theme of several reports. For instance, the 2008 report on global warming, details the effects of global warming which have been severe on the poor societies including health risks.

Recent trends suggest the uncertainties of climate change. These include climate vulnerability issues such as tsunami, hurricane, earthquakes, cyclones, flooding etc.

Environmental consumption has often proved to be at variance with sustainability particularly among the high income societies (Hobson,2003; Schor, 2005).This particular concern has provided contrasts between the high and low income societies. The 1998 human development report, Consumption for Human Development, provided linkages with sustainability and environmental consumption. It recounts that "environmental damage threatens both the earth's carrying capacity and people's coping capacity. And it may have serious consequences for future generations" (UNDP, 1998).

Rising consumption puts undue stress and tension on the environment and depletes non-renewable resources. This includes deleterious consumption of renewable resources through deforestation, land, air and sea pollution, fresh water depletion through com modification, overfishing, unsustainable food consumption etc. These disproportionate consumption patterns and lifestyles remain critical to any useful analysis of sustainable human development. This draws on the importance of human potentiality in the context of complex and competing capitalist resource exploitation. David Korten (1995) suggests "ecological revolution" to restore ecosystem degradation.

Economic freedom should be at the centre of sustainable human development (Sen, 1999).There is equally the need for more inclusive democracy particularly in its "liberal" form. Around the globe, this elusive phenomenon despite the spread of democracy since the 1990s creates more increasing problems for the attainment of sustainable human development. Democracy could create the capacity for governance including accountable and inclusive governance. It could also create a zero sum polity where the winner takes all particularly in the context of the majority, where the minority could be marginalized. This has been characteristic of most developing democracies in Africa.

Human security remains a core challenge to sustainable human development. The resurgence of new wars and local conflicts in the global South (Kaldor 1999), including the rise in human insecurity and terrorism have been at issue. In the Middle East, the rise of the terrorist group- Islamic State of Iraq and Syria (ISIS) and parts of Africa including the insurgent Boko Haram terrorism in North East 
Nigeria etc constitute new global security threats. There are similar threats to human development such as food security, hunger, xenophobic attacks in South Africa, resurgence of chronic diseases in the poor societies such as HIV/AIDS, Ebola Virus, Cancer, Fibroid etc, the rise in homophobic attacks and killings particularly in the United States - the June 12, 2016 attack in Orlando which left 49 dead and 53 wounded at the gay nightclub Pulse, which is perhaps the highest recorded homophobic attacks in the United States.

These trends point out the gap between sustainability and human development.

\section{LINKING HUMAN DEVELOPMENT TO SUSTAINABILITY}

Sustainable human development should deploy new indicators for its measurement within which resurgent human development challenges such as ecological and security threats, hunger, diseases, inequality, climate induced tensions and disaster could be measured within "natural and human" dimension factors. Such linkages should include their overall implications and the need for adequate policy response.

The two key approaches to human development measurement namely; the "evaluative aspect' and the "agency aspect" (Sen, 2002) have been largely short of comprehensive approach to HD measurement. The evaluative for instance, emphasizes the evaluation of human improvements .It uses human achievements as indicators of progress. The agency aspect centers on "what human beings can do to achieve such improvements, particularly through policy and political changes" (Fakudar- Par, 2003).

How do you evaluate and what basic universal criteria justifies the evaluation. What historic factors out played itself and resulted in the variables to evaluate as nations have varying degrees of historical, geographical, environmental, political and economic experiences. Are there "value judgments" on human achievements?. Environmental and geographical variations make a universal HDI difficult. Country and regional specific features could be differential factors in arriving at accurate analysis of HDI.

Again, the basic human capabilities emphasized in the HDI is indistinct. Which capability is preferred to the other? and what gives rise to such capabilities considering the wide range of human capabilities. Sen(1989) argued that ;

"Even if some capabilities deserve greater public attention than others, the relative importance of the capabilities can vary with social context-from one community or country to another, and from one point of time to another. Thus "the task of specification must relate to the underlying motivation of the exercise as well as dealing with the social values involved" (Sen, 1989).

Identifying what constitutes "underlying motivations" and "social values" varies.

Prioritizing capabilities is also a challenge to measuring human development. Policy framings should take cognizance of the differentiations in capabilities of both individuals and countries. Criteria to decide more important capabilities include; 'universally valued by people across the world' and the notion that such capabilities should be "basic" suggesting that their lack would foreclose many other capabilities'(Fakudar-Par, 2003).These are more of normative assumptions which inevitably do not delineate a clear understanding of 'value' from an empirical point of view. Thus, 'universal value' could be unattainable or could lack 'universal acceptability' with consideration to human perceptible differences as value may not be universal per say.

There are perhaps the more perverse challenge of racial discrimination which is not so often discussed in the human development literature. Sustainable human development may not thrive with the denial of equal status to humanity on the basis of racial origins, this constricts economic opportunities, violates human rights, civil liberties and undermines the potential for sustainable human development.

A sharp contrast is discernible among the white supremacists and points out the variations between sustainability and human development-Thus a range of indicators within the human development studies should be re-examined and enlarged within sustainability contexts. On gender basis, there is gender disparity on the bases of sex. Thus, gender inequality gaps have been a key problem in the sustainable human development paradigm. Jolly, et al;(2009) had indicated that there is a weak correlation between data from the developed and developing societies that several developing 
countries irrespective of their improved economic growth indicators, hardly do credibly on a number of social and human rights issues. They argue that economic indicators may not always be a determinant of human development as "countries can make significant progress in human development even with slow economic growth, at least for a decade or so".

Beyond this notion, sustainability within the human development discourse is critical to inclusive and participatory human development Noorbakhsh (1998); Ranis, et al;(2006); Fukuda-Parr,(2006)had argued on alternative Human Development Index and examined the redundancy of prevailing human development index, Noorbakhsh (1998) suggests "Modified Human Development Index"(MHDI) as an alternative. The HDI on the other hand is based on UNDP's perception of human development. HDI is implemented by specifying a minimum and a desirable or adequate value for each indicator of human development to form "deprivation indicator" "removal of obstacles" and "enlargement of choices" (Amadi \& Igwe, 2015).

The methodological approach has been criticized for being too simplistic, lacking a solid theoretical foundation and containing arbitrariness in giving equal weights to its components-an inaccurate reflection of value judgement (Ferroni \& Kanbur, 1990) Moreover it has been pointed out that while infant mortality and life expectancy can be calculated from basic routine demographic data, the calculation of literacy rates requires data from detailed censuses (UN,2010). However this has been a challenge in most developing countries fraught with inadequate data.

Another limitation of these indices is the assumption of viewing achievement relative to the "worst" or "best" (HDI) country in the sample. Thus, if life expectancy in a more developed country falls, the HDI for a less developed country would go up -an obviously baseless proposition. These criticisms notwithstanding, these measures particularly HDI continue to be a yard stick for measuring human development (UN, 2010).

Following the rise of China, the 2013 Human Development Report, The Rise of the South: Human Progress in a Diverse World, created novel meaning of such meteoric rise in global contexts. However, majority of the people of the global South still remain in deprivation with high incidence of poverty. The rise of the BRICS countries in general do not equate institutional development of the global South especially in sub-Sahara Africa(SSA).As the subsequent UNDP human development report suggests, Africa's human development index has been low( UNDP,2012) . The highlights of Africa Human Development Report 2012, Towards a Food Secure Future reads as follows;

- Sub-Saharan Africa's population, 856 million in 2010, is projected to exceed 2 billion shortly after 2050 .

- More than one in four Africans - close to 218 million people - is undernourished.

- Two major biases - towards towns rather than rural areas and towards men, not women - have been principal factors in explaining Africa's food insecurity.

- African governments spend between 5-10\% of their budgets on agriculture, well below the $20 \%$ average that Asian governments devoted to the sector during the green revolution there.

- Women are significant food producers, but their control of land in sub-Saharan Africa is less than in any other region.(UNDP Africa, 2012).

Beyond these, there has been high incidence of poverty despite the alleged rapid urbanization in Africa (Amadi, 2016).An average African subsists on less than \$2USD per day(Word Bank, 1991). Paul Collier's work, the Bottom Billion explicates the incidence of poverty and social vulnerability of the poor, the vast majority reside in Africa(Collier,2007).This is instructive of income inequality and poor social wellbeing( Birdsal,2005). Collier (2007) attributes the extreme poverty of the fiftyeight countries that harbor the poorest billion individuals to a combination, of four "traps": a conflict trap, a natural resources trap, the trap of being landlocked with bad neighbors, and a poor governance trap. He argued that these countries will likely end in "a ghetto of misery and discontent" (Collier, 2007). This micro level analysis of poverty underscores the prevailing challenges of human development among the Third World societies. 
Imperial (1996:3) argued on the importance of human development to the well- being of the poor, as she contends that demographic, economic and social factors are key determinants of poverty. And that human development should be a strategy for uplifting the economic condition of the poor.

Recent scholarship suggests the need for equity as a development goal (Robredo, 1994). In particular, the persistent challenge of urban renewal and green urbanization in sustainability contexts (Amadi,2016),draws attention to equitable and sustainable human development in the context of equal access to basic social amenities and infrastructure. In clear terms, economic growth in terms of GNP, GDP, or per capita income, appears meaningless if its benefits do not accrue more equitably to the people (ul Hag, 1995; Imperial, 1996). The presence of "more banks, commercial establishments, multinational subsidiaries cities contrasts economic growth where majority are poor" (Imperial, 1996, p.2).

Rodney(1972) provides a genealogical exploration of human development from "crude stone tools" to assuming a "social character" and argues that "the level of success of man is better appreciated with an insight on the early history of human society in which there was absence of economic exploitation of man by man.

Thus, man develops through rational thinking, greater freedom, self -discipline, adventure, skills, responsibility and adequate Stateness. These historical depictions largely linked to colonial and neo colonial historical depictions as critical to economic exploitation and the underdevelopment of the Third World. For instance, understanding the developing countries has been useful in contemporary human developing studies. It is worth noting that developing countries cover much of Asia, Africa and Latin America, as well as many parts of Eastern and Southern Europe well outside the tropics. Covering rather more than half the world's land surface, developing countries contain over two-thirds of the world's population(Buchanan,1964;Steel \& Prothero, 1967).Both Hodder (1968)and Bailley (1958) illustrate the complexity of any attempt to classify or categorize countries by levels of development: they demonstrate that while it may be true that most developing countries appear to be high on the demographic scale and low on the technological scale, there is no clear break in the spectrum between the less developed and more developed countries.

Myint (1964) laid emphasis on "type of underdeveloped country" not necessarily demographic, economic or poverty issues prevalent in the Third World. According to Myint (1964), certainly it is easy to over-generalize about developing countries, ignoring differences between densely populated and highly populated countries and between countries at widely differing levels of economic achievement. Perhaps the first thing to bear in mind about developing countries, indeed, is that 'beyond the broad common fact of poverty, it is rarely safe to make generalizations about them without first specifying the type of underdeveloped country one is considering.

Despite the absence of a clear delineation, terminological evaluation of some fundamental criteria has lent credence to classification of the Third World. Such criterion like development has often contrived an insightful understanding of the term. As Seers (1969) argued that development must answer the questions of poverty, unemployment and inequality not necessarily the rise in per capita income. This unit level analysis of development underscores the relevance of human development in the Third World and wider development discourse.

Another distinctive understanding of the Third World is the term "underdevelopment" correctly exemplified in the writings of Gunder Frank (1970), who argued that;

The now developed countries were never underdeveloped, though they may have been underdeveloped. It is also widely believed that the contemporary under development of a country can be understood as the product or reflection solely of its own economic, political, social and cultural characteristics or structure. Yet historical research demonstrates that contemporary underdevelopment is in large part the historical product of past and continuing economic and other relations between the satellite underdeveloped and the now developed metropolitan countries. Furthermore, these relations are an essential part of the structure and development of the capitalist system on a world scale as a whole. 
Related pertinent accounts associated with the Third World is poverty. On the incidence of poverty, Sachs (2005), argued that this very question has become our own (the affluent North). He then asked; Will we have the good judgment to use our wealth wisely, to heal a divided planet, to end the suffering of those still trapped by poverty, and to forge a common bond of humanity, security, and shared purpose across cultures and regions?(Sachs,2005).

In this context, sustainable human development policy framework should prioritize response to threats to sustainable human development in particular, provide stronger institutions, create inclusive alliances and development networks, active and participatory strong civil society, institutional checks and accountability, responsible and pro poor global governance.

\section{DISCUSSION}

Human well-being should be the basis of development. Thus, "the expansion of output and wealth is only a means" (UNDP,1990). Sustainability perhaps forms part of a distinct human development component since it particularly emphasizes long term human and eco system wellbeing. This is particularly important since the 1990s when the Human Development Index (HDI) formed the core of UNDP development discourse evolving from the institutional economic development approach, (GDP, National Income) and related Neo Liberal theories.

Although the UNDP's human development reports have been charting a seminal development cause as Fukudar -Par (2003,p.308) recounts that over 700 other human development reports have been prepared since 1992 at national, regional and local levels from 135 countries, progress at radical institutionalization of sustainable human development in practical contexts remains superficial. For instance, despite the postulations of first Human Development Report (HDR) which defined human development as the process of enlarging people's choices. The guarantee for freedom of choice remains bleak.

The most critical of these wide ranging choices are to live a long and healthy life, to be educated and to have access to resources needed for a decent standard of living additional choices include political freedom, guaranteed human rights and personal self -respect.

According to Fukudar-Par (2003) the report is not just any (emphasis as in the original) that the UNDP might commission on a given theme, nor is it a status report for monitoring development it has a much broader ambition, namely setting out a comprehensive approach to development ,including an agenda of policy priorities, tools of analysis and measurement, and a coherent conceptual framework.

Again, issues of long life, education and decent living were re-emphasized in 2001, (HDR, 2001; Fukudar -Par, 2003). Though, Sen (1989) improved on the human development paradigm within its definitional goals, suggesting that areas which were redefined in the evolution of human development as policy challenges from 1990 to 2011 have been broad. However, a number of gaps are discernible. For instance, its 1998 report which examined consumption did not clearly spell out the "unsustainable consumption and lifestyles of the high income nations" and its deleterious effects on the environment and the poor nations.

Despite the paradigm shifts resulting in the human development treatise, global policy inertia in rearticulating a less asymmetrical international system remains at issue. Neither has socio-economic inequality including racial discrimination abated considerably. Also "Sustainability and Equity" which formed the theme of the 2011 report was superficial in addressing the unsustainable consumption patterns of the affluent societies.

However, Fukudar -Par made a submission that, 'the human development approach is not a recipe of policy prescriptions with a set of "destinations" and a list of ingredients on how to get there. It claims to be instead a "robust paradigm" that can be used over time and across countries as development challenges and priorities shift". Notwithstanding, in the context of the current challenges that face most countries today, Fukudar -Par proposed five elements of a general human development agenda. Which he argued constitutes what might be called a "New York consensus", as these points are reflected in many UN agreements': 
Prince Igwe et al.

1. Priority to "social development" with the goal of expanding education and health opportunities

2. Economic growth that generates resources for human development in its many dimensions.

3. Political and social reforms for democratic governance that secures human rights so that people can live in freedom and dignity, with greater collective agency, participation, and autonomy.

4. Equity in the above three elements with a concern for all individuals, with special attention to the downtrodden and the poor whose interests are often neglected in public policy, as well as the removal of discrimination against women.

5. Policy and institutional reforms at the global level that create an economic environment more conducive for poor countries to access global markets, technology, and information (see Fukudar Par, 2003, p.312).

The human development and its implicit paradigm could be dialectically linked with the various themes of the report between 1990 and 2016 as table 1 below shows.

Table1. Human Development Reports and Themes 1990 -2016

\begin{tabular}{|l|l|}
\hline Year & Theme \\
\hline 1990 & Concept and Measurement of Human Development \\
\hline 1991 & Financing Human Development \\
\hline 1992 & Global Dimensions of Human Development \\
\hline 1993 & People's Participation \\
\hline 1994 & New Dimensions of Human Security \\
\hline 1995 & Gender and Human Development \\
\hline 1996 & Economic Growth and Human Development \\
\hline 1997 & Human Development to Eradicate Poverty \\
\hline 1998 & Consumption for Human Development \\
\hline 1999 & Globalization with a Human Face \\
\hline 2000 & Human Rights and Human Development \\
\hline 2002 & Deepening Democracy in a Fragmented World \\
\hline 2001 & Making New Technologies Work for Human Development \\
\hline 2003 & Millennium Development Goals: A Compact Among Nations to End Human Poverty \\
\hline 2004 & Cultural Liberty in Today's Diverse World \\
\hline 2005 & International cooperation at a crossroads: Aid, trade and security in an unequal world \\
\hline 2006 & Beyond scarcity: Power, poverty and the global water crisis \\
\hline $2007 / 8$ & Fighting climate change: Human solidarity in a divided world \\
\hline 2009 & Overcoming barriers: Human mobility and development \\
\hline 2010 & Overcoming Barriers: Human Mobility and Development, \\
\hline 2011 & Sustainability and Equity: A Better Future for All \\
\hline 2013 & The Rise of the South: Human Progress in a Diverse World \\
\hline 2014 & Sustaining Human Progress: Reducing Vulnerabilities and Building Resilience \\
\hline 2015 & Work for Human Development \\
\hline 2016 & Human Development for Everyone \\
\hline
\end{tabular}

Source: Authors

\section{Conclusion}

In this context without the sustainability component, human development treatise will continue to remain a mere rhetoric. For instance the paradigm appears not to have significantly influenced global development thinking and practice among the affluent societies despite the robust offshoot since the 1990s.It has been argued that "UN operations still exists more as a hope and a vision than as a reality"(Jolly, et al;2009). Jolly, et al;(2009)further contend that the problems are more complex “" when the UN fails to show how the objectives and programs of peace, economic and social development, and human rights go well beyond the narrower economic philosophies and more limited objectives of the Bretton Woods institutions".

Thus, the sustainability component of human development must reassert some new and radical relevance in which the wider human development objectives could be achieved. This could be restored through a new development blue print with clear policy framework on sustainable human development 


\section{REFERENCES}

[1] Alkire S. (2010). Human Development: Definitions, Critiques, and Related Concepts Background paper for the 2010 Human Development Report. Oxford Poverty \& Human Development Initiative (OPHI) OPHI WORKING PAPER NO. 36 pp 154

[2] Amadi, L \& Igwe, P. (2015 ). Reconceptualising Poverty Measurement for Sustainable Development: Review of the Literature Research on Humanities and Social Sciences Vol.5, No. $18,42-55$

[3] Amadi, L.( 2016). "Urbanization and sustainable development in Africa: Problems and prospects." In Ukase, P. I., Akubor, E. O. and Onoja, A. I. Eds. Urbanization, security, and development issues in Nigeria 1914-2014, festschrift in honour of Professor Enoch Oyedele. Zaria: Ahmadu Bello University Press Limited, 2Pp. 131-160.

[4] Amin,S.(1972).Underdevelopment and Dependency in Black Africa Origins and Contemporary Form .Journal of Modern African Studies ,10.(4):503-24.

[5] Annand, S \& Sen, A. (1994).Sustainable Human Development: Concepts and Priorities Harvard University Cambridge, MA.

[6] Ayoob, M . (1995). The Third World Security Predicament; State Making, Regional Conflict and the International System. Lynne Rienner Publishers.

[7] Bailey, F. (1958).Caste and the Economic Frontier .London.

[8] Bello, W.(2003).De-globalization :Ideas for a New World Economy .Canada: Fernwood

[9] Birdsal N. (2005).Why Inequality Matters in a Globalizing World Helsinki, Washington Center for Global Development. WIDER Annual Lecture pp1-54

[10] Biersack, A. (1999). From the "new ecology" to the new ecologies. American Anthropologist 101(1): 5-18.

[11] Blaikie, P and Brookfield, H. (1987) .Land Degradation and Society. London: Methuen.

[12] Bourguignon, F.(2016).Inequality and Globalization. How the Rich Get Richer as the Poor Catch Up Foreign Affairs.

[13] Bourguignon, F., Bénassy-Quéré, A., Dercon, S., Estache, A., Gunning, J. W., Kanbur, R., et al. (2008).Millennium Development Goals at Midpoint: Where do we stand and where do we need to go? Background paper for European Report on Development 2009.

[14] Buchanan, K. (1964).Profiles of the Third World, Pacific View. Point,5, Clemens, M \& Moss, T. (2005). What's wrong with the Millennium Development Goals? Centre for Global Development.

[15] Collier, P.(2007).The Bottom Billion: Why the Poorest Countries Are Failing and What Can Be Done About It. New York: Oxford University Press.

[16] De Castro, J.(1952).The Geography of Hunger. Boston.

[17] Dos Santos, T. (2002). La Teoría de la Dependencia: Balance Perspectivas. Buenos Aires: Plaza \& Janes

[18] Dos Santos T. (1970).The Structure of Dependency the American Economic Review 60(2):231236.

[19] Easterly, W. (2009). How the Millennium Goals are Unfair to Africa, New York University, New York, NY, USA The Brookings Institution, Washington DC, USA World Development Vol.3pp.

[20] Escobar, A.(1995). Encountering Development: The Making and Unmaking of the Third World Princeton, N.J.

[21] Esteva, G. (1992). "Development”. In: Wolfgang Sachs (ed.). The development dictionary: A guide to knowledge as power. London: Zed Books Ltd. PP 6-25.

[22] Ferguson, J.(2006). Decomposing Modernity: History and Hierarchy after Development Department of Anthropology University of California, Irvine.

[23] Ferroni. M \& Kanbur. R, (1990) Poverty-conscious Restructuring of Public Expenditure World Bank .Oxford Press. 
[24] Frank, A. (1970) Latin America: Underdevelopment or Revolution. New York :Monthly Review Press

[25] Fukudar -Par, S.(2003).The Human Development Paradigm :Operationalizing Sen's Ideas on Capabilities, Routledge Feminist Economics 9(2-3), $301-317$

[26] Harvey, D.(2005).Brief History of Neoliberalism; New York: Oxford University Press.

[27] Hinrinchsen D, Salem,R., and Blackburn, R.(2002). Meeting the Urban Challenge. Population Reports, Series M, No. 16. Baltimore, The Johns Hopkins Bloomberg School of Public Health, Population Information Program.

[28] Hobson, K.(2003).Consumption, Environmental Sustainability and Human Geography in Australia: A Missing Research Agenda?.Australian Geography Studies.41(2)148 155

[29] Hodder, B. (1968) .Economic Development in the Tropics Methuen \& Co Ltd. London

[30] Institute on Chuch and Social Issues. (1992). This Urban Land: Ours Too! (Statement of the Urban Poor Organization on Proposed Urban Development and Housing Act of 1991. In PULSO (Pagsusurisa Lipunan at Simbahan) Monograph No. 11, May 1992. Institute on Church and Social Issues, Social Development Complex, Ateneode Manila University Campus, Loyola Heights, Quezon City.

[31] Imperial, S. (1996). Development and the Urban Poor: Bridging the gap between research and users Journal of the Ateneo de Naga, Vol. III, No. 1.

[32] Jolly R, Emmerij L and Weiss T(2009). The UN and Human Development Briefing Note United Nations Intellectual History Project - Ralph Bunche Institute for International Studies

- The CUNY Graduate Center - www.UNhistory.org

[33] Kadir, A. (2005).Understanding Urban Chronic Poverty: Crossing the Qualitative and Quantitative Divide .Department of Economics University of Leicester L E17RH, United King dom CPRC Working Paper 53.

[34] Kaldor, M. (1999). New and Old Wars: Organized Violence in a Global Era (3 ${ }^{\text {rd }} \quad$ Edition), Cambridge: Polity Press

[35] Goodland, R. (1995).The Concept of Environmental Sustainability. Annual Review of Ecology and Systemics, Volume 26,1-24.

[36] Korten, D. (1995) . When Corporations Rule the World Kumarian Press.

[37] Lewis, A.(1955). The Theory of Economic Growth. London.

[38] Mazuri, A .(1995). African State as a Political Refugee In:David Smock and Chester Crocker,African Conflict Resolution; The US Role in Peacemaking Washington DC;United States Institute of Peace Press

[39] Morris, M. (1980). "The Physical Quality of Life Index (PQLI).". Development digest.18 (1): 95-109.

[40] Myint,H .(1964 ). The Economics of the Developing Countries.London

[41] Nandy, A. (1983). The intimate enemy: Loss and Recovery of self under colonialism. Oxford: Oxford University Press.pp xi

[42] Narayan, D., Patel, R., Schafft, K., Rademacher, A., \& Koch-Schulte, S. (2000). Voices of the poor: can anyone hear us? Oxford: Oxford University Press.

[43] Noorbakhsh.F. (1998).The Human Development Index: Some Technical Issues and Alternative Indices Journal of International Development . 10, 589-605.

[44] Pieterse, J. (2010). Development theory: Deconstructions / reconstructions. London: Sage Publications Ltd. 2nd Edition.

[45] Piketty T \& Saez,E .(2003). "Income Inequality in the United States, 1913-1998," Quarterly Journal of Economics, 118(1).

[46] Ranis, G, Stewart F and Samman, E(2006) Human Development: Beyond the HDI In Poverty In Focus International Poverty Centre .United Nations Development Programme.

[47] Robredo, J. (1994). The Naga Kaantabay sa Kauswagan Program: "Empowering the Urban Poor". Paper presented during the 10th Cities Sharing Workshop on April 27, Naga City. 
[48] Rodney, W. (1972).How Europe Underdeveloped Africa. Washington DC. Howard University Press

[49] Rostow W. (1960). The Stages of Economic Growth, Cambridge

[50] Sachs, J. (2005).The End of Poverty. The Penguin Press,

[51] Sachs, W. (1992).The Development Dictionary: A guide to knowledge as power. London: Zed Books.

[52] Salazar, R \& Lynch,F. (1974). Happiness Starts with a Good Job and a Good Home So Say the People of the Bicol River Basin. SSRU Research Report Series No.12. Social Science Rese arch Unit (SSRU), Ateneo de Naga, Naga City.

[53] Schor, J. (2005).Prices and quantities: Unsustainable consumption and the global economy, Ecological Economics 55. 309- 320

[54] Schultz, T. (1964).Investment in human capital, American Economic Review, 51.

[55] Seers, D. (1969). 'The Meaning of Development'. Eleventh World Conference of the Society for International Development, New Delhi.

[56] Sen, A. (1989). Development as Capability Expansion. Journal of Development Planning, 17 , 41-58.

[57] Sen, A (1999). Development as Freedom. Oxford: Oxford University Press.

[58] Sen, A .(2002). "Foreword," in Sakiko Fukuda-Parr and A.K. Shiva Kumar (eds.) Human Development, Essential Readings. New Delhi: Oxford University Press.

[59] Skocpol, T. (1977). Wallerstein's World Capitalist System: A Theoretical and Historical Critique. American Journal of Sociology, Vol. 82. N. 5. 1075-1090.

[60] Steel,R \& Prothero R (eds).(1967).Geographers and the Tropics. London

[61] Sewell, J. (1998). Challenges of Globalization .Human Rights Dialogue 1.11 (Summer 1998) "Toward a "Social Foreign Policy" with Asia"

[62] Stiglitz, J. (2016).Globalization and its New Discontents. Project Syndicate. Available at "https://www.projectsyndicate.org/default/library/c198d0035bc7db1aa409717cfm020935.square. pg" itemprop= "thumbnailul Hag, M.(1995).Reflections on human Development .New York: Oxford University Press.

[63] UN. (2010). Rethinking Poverty: Report on the World Social Situation (RWSS) [Online] Available: http://www.un.org/esa/socdev/rwss/2010.html9 Accessed98/31/2017).

[64] UNDP, (1990). Human Development Report. New York. Oxford. Oxford University Press.

[65] UNDP. (1994). Human development report 1994: New dimensions of human security. New York: Oxford University Press.

[66] UNDP. (1996). Human development report 1996: Economic growth and human development New York: Oxford University Press.

[67] UNDP. (2008). Human development report 2007/2008: Fighting climate change: human solidarity in a divided world New York: Palgrave.

[68] UNDP.(2016) ."Human Development Report 2016: Human Development for Everyone" New York, Oxford University Press.

[69] United Nations Development Programme (1998). Human Development. Report New York :Oxford University Press.

[70] UNDP. (2012). The Human Development Report,(2012) The Rise of the South: Human Progress in a Diverse World, New York Oxfrod University Press

[71] Wallerstein, I .(1976) World System Analysis: the second Phase'.Review,XIII,No.2,Spring.

[72] Weinstein B. ( 2008), Developing Inequality, American Historical Review v. 113, no. 1 pp. $1-18$.

[73] Worzel .R. (1994). Facing the Future; The Seven Forces Revolutionalizing Our Lives, Stoddart Publishing Co.Limited,34 Lesmill Road, Toronto Canada

[74] World Bank. (1991). World Development Report 1991: The Challenge of

[75] Development Oxford, New York, Toronto: Oxford University Press. 
Prince Igwe et al.

[76] World Bank. (1998). World Development Report 1998: Oxford, New York, Toronto: Oxford University Press.

[77] World Bank. (2016). World development report. Washington, DC: Oxford University Press.

[78] World Commission on Environment and Development (WCED) (1987). Our Common Future. Oxford Press.

Citation: Prince, Igwe et al. "Human Development and Sustainability Nexus: A Third World Perspective." International Journal of Political Science (IJPS), vol 3, no. 4, 2017, pp. 1-14. doi:http://dx.doi.org/ 10.20431/2454-9452.0304001.

Copyright: (๑) 2017 Authors. This is an open-access article distributed under the terms of the Creative Commons Attribution License, which permits unrestricted use, distribution, and reproduction in any medium, provided the original author and source are credited. 